\title{
Sickle cell-hemoglobin D disease syndrome
}

INSERM

\section{Source}

INSERM. (1999). Orphanet: an online rare disease and orphan drug data base. Sickle cellhemoglobin D disease syndrome. ORPHA:251370

\begin{abstract}
A rare, genetic hemoglobinopathy characterized by anemia and erythrocyte abnormalities including anisocytosis, poikilocytosis, target cells, and irreversibly sickled cells. Clinical course is similar to sickle cell disease, including acute episodes of pain, splenic infarction and splenic sequestration crisis, vaso-occlusive crisis, acute chest syndrome, ischemic brain injury, osteomyelitis and avascular bone necrosis.
\end{abstract}

